\title{
EVALUATION OF PHYTOCHEMICAL CONSTITUENTS AND ANTIOXIDANT ACTIVITIES OF DIFFERENT FORMULA OF HEART TONIC HERBAL TEAS
}

\author{
RACHANEE NAMMATRA*1, THANIDA SRIHAWONG ${ }^{2}$ AND CHINNAPHAT \\ CHALOERMRAM ${ }^{1}$
}

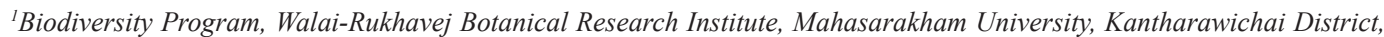
Maha Sarakham 44150, Thailand. ${ }^{2}$ Veterinary Technology and Veterinary Nursing Program, Faculty of Agricultural Technology, Rajabhat Mahasarakham University, Mueang Maha Sarakham District, Maha Sarakham, 44000, Thailand.

*Corresponding author: rachanee.n@msu.ac.th

Submitted final draft: 31 August $2020 \quad$ Accepted: 5 September 2020

http://doi.org/10.46754/jssm.2021.02.010

\begin{abstract}
Heart tonic herbal teas were developed to select herbal teas to enhance cardiovascular health. The herbal teas were separated into 2 formulas: first, Pleurotus ostreatus: Pandanus amaryllifolius: Oryza sativa cv. KDML 105 (brown rice): Oryza sativa cv. KDML 105 (leaves): Clitoria ternatea; 1: 1:1:1:1 (w:w:w:w;w) and second, Ganoderma lucidum: Caesalpinia sappan: Aegle marmelos: Chrysanthemum indicum: Carthamus tinctorius; 1:1:1:1:1 (w:w:w:w;w), which were extracted with aqueous infusion. Phytochemical screening was used to examined flavonoid and phenolic acid compounds, using High-Performance Liquid Chromatography (HPLC), and the total phenolic content (TPC) and total flavonoid content (TFC) of the extracts were determined. The antioxidant activity was determined using 2,2-diphenyl-1-picrylhydrazy (DPPH) radical scavenging and Ferric reducing antioxidant Power (FRAP) assay. The results showed that the second formula contained significantly higher TPC, TFC, flavonoid compounds and phenolic compounds than the first formula. Antioxidant activities with DPPH and FRAP assay of the second formula $\left(16.88 \pm 0.25 \mathrm{mgTE} / \mathrm{g}\right.$ and $62.97 \pm 2.45 \mathrm{mM} \mathrm{Fe}{ }^{2+} \mathrm{E} / \mathrm{g}$, respectively) was significantly higher than the first formula $\left(5.41 \pm 0.03 \mathrm{mgTE} / \mathrm{g}\right.$ and $13.57 \pm 1.10 \mathrm{mM} \mathrm{Fe}^{2+}$ $\mathrm{E} / \mathrm{g}$, respectively). These findings indicated that the second formula of the heart tonic herbal tea has an inhibitory free radical effect and has the potential to improve cardiovascular health following its consumption.
\end{abstract}

Keywords: Heart Tonic Herbal Teas, CVDs, Phytochemical screening, Antioxidant.

\section{Introduction}

Cardiovascular diseases (CVDs) are a group of disorders of the heart and blood vessels and they include coronary heart diseases, cerebrovascular diseases, rheumatic heart diseases, peripheral arterial diseases, congenital heart diseases, deep vein thrombosis and pulmonary embolism and other conditions. CVDs are the No. 1 cause of death globally, taking an estimated 17.9 million lives each year (WHO, 2017). Previously, it was predicted that by 2020, CVDs would be the most common cause of death (Trivedi \& Nehra, 2004). The major risk factors for CVDs include family history, sex, raised lipid levels, hypertension, obesity, cigarette smoking, hypercholesterolemia, diabetes, and other lipid abnormalities. According to the National Health Survey of Thailand, about 20,000 deaths occur per year in the country due to CVDs. Many synthetic drugs have been commonly used for the treatment of these diseases, but herbal medicines remain the popular choice in ThirdWorld countries (Akhtar et al., 2013). According to a World Health Organisation (WHO) survey, approximately $60 \%$ of the world's population rely on traditional herbal medicines (Zhang, 2000).

Free radicals cause many illnesses in humans, especially chronic diseases, such as cancer, heart disease, cerebrovascular disease, hypertension, kidney disease, cataract, and gout, through multiple mechanisms (Chan et al., 2006). Oxidative stress has been shown to be actively involved in the development of CVDs, as well as cardiovascular-related complications by dysfunction of vascular smooth muscle cells, endothelial cells, and mononuclear cells, which can ultimately lead to CVDs (Higashi et al., 2006; 
Zhang et al., 2014). In recent years, numerous studies have reported that phytochemicals from plants have antioxidant potential, which are risk factors for many diseases (Duthie \& Crozier, 2000).

Herbal teas, or more accurately known as tisanes, are mixtures of dried leaves, seeds, grasses, nuts, barks, fruits, flowers, or other plant parts that give them their flavor and provide therapeutic benefits (Ravikumar, 2014). In Thailand, they have gained popularity in recent years and are available in a variety of health food stores. Many herbal companies are interested in the production and distribution of herbal teas made from a variety of medicinal plants. Herbal teas are sold as ground herbs packed in tea bags, which can be consumed by steeping them in hot water. In addition, they are popular due to their pleasant fragrance, antioxidant properties and therapeutic applications (Chan et al., 2012).

Heart tonic herbal teas have been developed to be an alternative in the enhancement of cardiovascular health and prevention of cardiovascular diseases. In this study, we selected 2 herbal teas with equal amounts of different herbal components in order to compare their phytochemical composition and antioxidant capacity. The first formula is composed of Pleurotus ostreatus, Pandanus amaryllifolius (leaf), Oryza sativa cv. KDML 105 (brown rice), Oryza sativa cv. KDML 105 (leaf) and Clitoria ternatea (flower). The second formula is composed of Ganoderma lucidum, Caesalpinia sappan (heartwood), Aegle marmelos (fruit), Chrysanthemum indicum (flower) and Carthamus tinctorius (flower).

A literature review related to the treatment of cardiovascular disease found that the phytochemical of P. ostreatus (Oyster mushroom) extract contained terpenoids, tanins, steroidal glycosides, carbohydrates, amino acid, vitamin $\mathrm{B}$, and phenolic compounds (Iwalokun et al., 2007). It has been shown to inhibit the activity of Type-2 diabetes in rats (Zhang et al., 2016) and anti-hyperlipidaemic in hypercholesterolemic rats (Bobek et al., 1997; Alam et al., 2011), as well decrease the levels of blood pressure and blood glucose in people (Choudhury et al., 2015). The extract of $P$. amaryllifolius Roxb. leaves contains several compounds that act as a natural antioxidant and antidiabetic agents, such as essential oils, tocopherols, tocotrienols, alkaloid fatty acids, esters non-specific lipid transfer protein, carotinoids and flavonoids (Chiabchalard et al., 2015). O. sativa cv. KDML 105, or Thai jasmine rice, is known as one of the highest quality rice varieties in Thailand (Semsang et al., 2012). In addition, various parts of the rice, such as seeds, paddy, leaves, roots, rice stalks and boiling milk-like water, are used as Thai herbs to treat diseases. The seeds of Thai jasmine rice contain phytochemicals, such as carbohydrates, $\gamma$-aminobutyric acid (GABA), vitamin B, phytic acid, tocotrienols and phenolic compounds (Sripum et al., 2017). Preliminary phytochemical screenings of the extract of $C$. ternatea flowers showed that they contained tannins, phlobatannin, carbohydrates, saponins, triterpenoids, phenols, flavanoids, flavonol glycosides, proteins, alkaloids, antharaquinone, anthocyanins, cardiac glycosides, stigmast-4-ene-3,6-dione, volatile oils and steroids (Al-Snafi, 2016). It has been shown to have antihyperglycemic and antihyperlipidemic effects in alloxan-induced diabetic rats (Daisy et al., 2009).

The phytochemical of $G$. lucidum extract contains carbohydrates, glycosides, triterpenoids, steroids, phenolic compounds, and tannins, which decreased blood pressure and lipid levels in spontaneously hypertensive rats (Kabir et al., 1998). The extract of C. sappan heartwood contains tannin, phenolic compounds, and several aromatic compounds, such as brazilin, brasilein, phellandrene, ocimene, sappanin and caesalpin (Pawar et al., 2008). Brazilin isolated from $C$. sappan heartwood induces vasodilation of rat aorta (Yan et al., 2015). The bael fruit (A. marmelos) contains many functional and bioactive compounds, such as carotenoids, phenolics, alkaloids, coumarins, flavonoids, and terpenoids (Charoensiddhi \& Anprung, 2008), which have been shown to act as an antidiabetic (Kamalakkannan \& Prince, 2003) and antihyperlipidaemic in streptozotocin diabetic rats (Kamalakkannan \& Prince, 2004). The 
phytochemicals of $C$. indicum flower extract contains flavonoids, terpenoids, phenolic compounds, vitamin and amino acid, which has anti-hypertensive and anti-stroke effects in stroke-prone spontaneously hypertensive rats (Zhao et al., 2008). Furthermore, caryophyllene, p-allyltoluene, 1-acetoxytetralin and heneicosane have been identified as the major components of essential oils of $C$. tinctorius flowers, which have hypolipidemic effects (Rahimi et al., 2014) and they reduce the blood pressure (Prasattong et al., 2014) in diabetic rats.

Nevertheless, these herbal tea formulas were first developed as an alternative to enhancing cardiovascular health. Therefore, this study aims to determine the phytochemical (TPC, TFC and HPLC assay) and antioxidant activities (DPPH and FRAP assay) for confirmed pharmaceutical preliminaries, as well as to compare the phytochemical composition and antioxidant capacity of the two formulas of the best qualified heart tonic herbal teas.

\section{Materials and methods}

\section{Materials}

The heart tonic herbal teas were developed based on equal amounts of different herbal ingredients to compare their phytochemical composition and antioxidant capacity. The first formula was composed of Pleurotus ostreatus: Pandanus amaryllifolius (leaves): Oryza sativa cv. KDML 105 (brown rice): Oryza sativa cv. KDML 105 (leaves): Clitoria ternatea (flower); 1:1:1:1:1 (w:w:w:w;w). The second formula was composed of Ganoderma lucidum: Caesalpinia sappan (heartwood): Aegle marmelos (fruits): Chrysanthemum indicum (flowers): Carthamus tinctorius (flowers); 1:1:1:1:1 (w:w:w:w;w). All the fresh materials were cleaned and dried at 45$60^{\circ} \mathrm{C}$ for $48 \mathrm{~h}$ in a hot air oven and then powdered as shown in Table 1.

\section{Preparation of Extracts}

For extraction from teas, $1 \mathrm{~g}$ of tea in powder form was extractedby immersing in $75 \mathrm{~mL}$ of water at $80{ }^{\circ} \mathrm{C}$ for $15 \mathrm{~min}(1: 75 \mathrm{w} / \mathrm{v})$. Extracts were filtered through a $0.45 \mu \mathrm{m}$ membrane filter. The extracts were separated into two parts. Part 1 was stored at $4^{\circ} \mathrm{C}$ for analysis of TPC, TFC, DPPH and FRAP assay. Part 2 was stored at $-18^{\circ} \mathrm{C}$ for analysis of HPLC. Analyses of aqueous tea extracts were done in triplicate.

\section{Determination of Total Phenolic Content (TPC)}

The total phenolic content was determined according to a modified procedure from Singleton et al. (1999). The extracts of the herbal tea formulas $(100 \mu \mathrm{L})$ were oxidized with $500 \mu \mathrm{L}$ of $0.2 \mathrm{~N}$ Folin-Ciocalteu's reagent and neutralized by adding $400 \mu \mathrm{L}$ of $7.5 \% \mathrm{Na}_{2} \mathrm{CO}_{3}$. The absorbance was measured at $765 \mathrm{~nm}$ by a UV-Vis spectrophotometer after being mixed and incubated in room temperature for 30 min. The results were expressed as gallic acid equivalent (mgGE/gExt).

\section{Determination of Total Flavonoid Content (TFC)}

The flavonoid content was estimated using the aluminum chloride colorimetric method (Sharma \& Agarwal, 2015). The extracts from the herbal tea formulas $(500 \mu \mathrm{L}), 2,000 \mu \mathrm{L}$

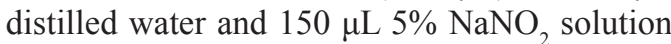
were added. After $6 \mathrm{~min}$, a $150 \mu \mathrm{L} 10 \% \mathrm{AlCl}_{3}$ solution was added and kept for another $6 \mathrm{~min}$. To this reaction mixture, $2,000 \mu \mathrm{L} 4 \% \mathrm{NaOH}$ solution and $200 \mu \mathrm{L}$ water was added to make up the final volume of $5,000 \mu \mathrm{L}$. The reaction mixture was mixed well and allowed to stand for $15 \mathrm{~min}$, after which absorbance was recorded at $510 \mathrm{~nm}$. The total flavonoid content (TFC) was calculated from a standard rutin equivalent (mgRE/gExt).

\section{High-Performance Liquid Chromatography (HPLC) Analysis}

Analyses were conducted to compare the amount of some flavonoid and phenolic acid compounds that were potentially beneficial in the herbal tea formulas using the High-Performance Liquid Chromatography (HPLC) method according to Jorjong et al. (2015). The HPLC-DAD system (Shimadzu, Kyoto, Japan), comprising Shimadzu LC-20AC pumps, a SPD-M20A diode array 
Table 1: Details of the composition, parts used, ratio, harvesting time, drying and the source of raw materials

\begin{tabular}{|c|c|c|c|c|c|}
\hline Materials & $\begin{array}{l}\text { Parts } \\
\text { Used }\end{array}$ & Ratio & $\begin{array}{l}\text { Harvest } \\
\text { time }\end{array}$ & Drying & $\begin{array}{c}\text { Raw material source (in } \\
\text { Thailand) }\end{array}$ \\
\hline \multicolumn{6}{|l|}{$1^{\text {st }}$ Formula } \\
\hline Pleurotus ostreatus & $\begin{array}{l}\text { Fruiting } \\
\text { body }\end{array}$ & 1 & $3-4$ month & $60^{\circ} \mathrm{C} / 48 \mathrm{~h}$ & $\begin{array}{l}\text { Lom and Fon Organic Farm } \\
\text { Co., Ltd., Udon Thani province }\end{array}$ \\
\hline $\begin{array}{l}\text { Pandanus } \\
\text { amaryllifolius }\end{array}$ & Leaves & 1 & - & $45^{\circ} \mathrm{C} / 48 \mathrm{~h}$ & $\begin{array}{l}\text { Thong In pharmacy Co.,Ltd., } \\
\text { Maha Sarakham province }\end{array}$ \\
\hline $\begin{array}{l}\text { Oryza sativa cv. } \\
\text { KDML } 105\end{array}$ & $\begin{array}{l}\text { Brown } \\
\text { rice }\end{array}$ & 1 & $6-7$ month & $45^{\circ} \mathrm{C} / 48 \mathrm{~h}$ & $\begin{array}{l}\text { farmer in Kham Riang sub } \\
\text { district, Kantharawichai district, } \\
\text { Maha Sarakham province }\end{array}$ \\
\hline $\begin{array}{l}\text { Oryza sativa cv. } \\
\text { KDML } 105\end{array}$ & Leaves & 1 & $3-4$ month & $45^{\circ} \mathrm{C} / 48 \mathrm{~h}$ & $\begin{array}{l}\text { farmer in Kham Riang sub } \\
\text { district, Kantharawichai district, } \\
\text { Maha Sarakham province }\end{array}$ \\
\hline Clitoria ternatea & Flowers & 1 & - & $45^{\circ} \mathrm{C} / 48 \mathrm{~h}$ & $\begin{array}{l}\text { Thong In pharmacy Co.,Ltd., } \\
\text { Maha Sarakham province }\end{array}$ \\
\hline \multicolumn{6}{|l|}{$2^{\text {nd }}$ Formula } \\
\hline Ganoderma lucidum & $\begin{array}{l}\text { Fruiting } \\
\text { body }\end{array}$ & 1 & $3-4$ month & $\begin{array}{l}60^{\circ} \mathrm{C} / \\
48 \mathrm{~h}\end{array}$ & $\begin{array}{l}\text { Chok Taweesap Mushroom } \\
\text { Farm, Maha Sarakham province }\end{array}$ \\
\hline Caesalpinia sappan & $\begin{array}{l}\text { Heart } \\
\text { wood }\end{array}$ & 1 & - & $\begin{array}{l}45^{\circ} \mathrm{C} / \\
48 \mathrm{~h}\end{array}$ & $\begin{array}{l}\text { Thong In pharmacy Co.,Ltd., } \\
\text { Maha Sarakham province }\end{array}$ \\
\hline Aegle marmelos & Fruits & 1 & - & $\begin{array}{l}45^{\circ} \mathrm{C} / \\
48 \mathrm{~h}\end{array}$ & $\begin{array}{l}\text { Thong In pharmacy Co.,Ltd., } \\
\text { Maha Sarakham province }\end{array}$ \\
\hline $\begin{array}{l}\text { Chrysanthemum } \\
\text { indicum }\end{array}$ & Flowers & 1 & - & $\begin{array}{l}45^{\circ} \mathrm{C} / \\
48 \mathrm{~h}\end{array}$ & $\begin{array}{l}\text { Thong In pharmacy Co.,Ltd., } \\
\text { Maha Sarakham province }\end{array}$ \\
\hline Carthamus tinctorius & Flowers & 1 & - & $\begin{array}{l}45^{\circ} \mathrm{C} / \\
48 \mathrm{~h}\end{array}$ & $\begin{array}{l}\text { Thong In pharmacy Co.,Ltd., } \\
\text { Maha Sarakham province }\end{array}$ \\
\hline
\end{tabular}

detector and an Apollo C-18 column (Alltech Associates, Deerfield, IL, USA) (4.6 mm x 250 $\mathrm{mm}, 5 \mu \mathrm{m})$ protected with guard column Inertsil ODS-3 (4.0 mm x $10 \mathrm{~mm}, 5 \mu \mathrm{m})$ (GL Science Inc., Tokyo, Japan) were used for the analysis of flavonoids and phenolic acids. The mobile phase for flavonoids used acetonitrile/deionized water $(2 / 97.8, \mathrm{v} / \mathrm{v})$ containing $0.2 \%$ phosphoric acid (solvent A) and acetonitrile/deionized water $(97.8 / 2, \mathrm{v} / \mathrm{v})$ containing $0.2 \%$ phosphoric acid (solvent B) at a flow rate of $0.6 \mathrm{ml} / \mathrm{min}$ and $40^{\circ} \mathrm{C}$ column temperature. The UV-Vis spectra were detected at $254 \mathrm{~nm}$. (Butkhup \& Samappito, 2008). The mobile phase for phenolic acids consisted of acetonitrile (solvent A) and phosphoric acid in deionized water $\mathrm{pH} 2.58$ (solvent B) at a flow rate of $0.8 \mathrm{ml} / \mathrm{min}$ and $40^{\circ} \mathrm{C}$ column temperature. The content of flavonoid compounds were catechin, myricetin, quercetin and kaempferol, and the phnolic compounds, including gallic acid, syringic acid and cumaric acid, were analyzed by comparing the retention time and spectrum, as well as standard addition.

\section{Antioxidant Activity by DPPH Assay}

2,2-Diphenyl-1-picrylhydrazyl (DPPH) radical scavenging capacities of extracts were estimated by the reduction of the reaction color between the DPPH solutions and sample extracts, as previously described by a prior method by Ursini et al.(1994). The DPPH was dissolved in ethanol to a concentration of $0.039 \mathrm{mg} / \mathrm{mL}$. The formula of extract at various concentrations was diluted with distilled water to provide sample solutions, $100 \mu \mathrm{L}$ of the sample solution, 
following which $900 \mu \mathrm{L}$ DPPH $(0.1 \mathrm{mM})$ working solution. After a $30 \mathrm{~min}$ reaction, which was kept in the dark at ambient temperature, the absorbance of the solution was measured at $515 \mathrm{~nm}$. In this study, Trolox ${ }^{\circledR}$ was used as a standard substance. Blanks were run in each assay. The DPPH radical ability was expressed as $\mathrm{IC}_{50}(\mathrm{mg} / \mathrm{mL})$ and the inhibition percentage was calculated using the following formula:

DPPH scavenging activity $(\%)=\left[\left(\mathrm{A}_{0}-\mathrm{A}_{\mathrm{S}}\right) / \mathrm{A}_{0}\right] \times 100$

Where $\mathrm{A}_{0}$ of control is the absorbance of the solvent mixed with DPPH solution and $A_{S}$ is the absorbance of the extract solution.

\section{Ferric Reducing Antioxidant Power (FRAP) Assay}

The FRAP assay was conducted according to previous method (Benzie \& Strain, 1996). The working solution was prepared by mixing $25 \mathrm{~mL}$ of acetate buffer $\mathrm{pH} 3.6$ (3.1 g of $\mathrm{CH}_{3} \mathrm{COONa} .3 \mathrm{H}_{2} \mathrm{O}$ and $16 \mathrm{~mL}$ of $\mathrm{CH}_{3} \mathrm{COOH}$ ) to a concentration of $300 \mathrm{mM}, 2.5 \mathrm{~mL}$ TPTZ solution $(10 \mathrm{mM}$ TPTZ in $40 \mathrm{mM} \mathrm{HCl})$ and $2.5 \mathrm{~mL}$ of $20 \mathrm{mM} \mathrm{FeCl} \cdot 6 \mathrm{H}_{2} \mathrm{O}$ solution and incubating at $37{ }^{\circ} \mathrm{C}$ before use. Samples have a concentration of $1500 \mu \mathrm{g} / \mathrm{mL}(200 \mu \mathrm{L})$ and could react with $2.5 \mathrm{~mL}$ of the working solution for $30 \mathrm{~min}$ in dark at $37^{\circ} \mathrm{C}$. Absorbance was measured at $593 \mathrm{~nm}(\mathrm{n}=3)$ using a UV-Vis spectrophotometer. Ferrous sulfate $\left(\mathrm{FeSO}_{4}\right)$ was used as standard to establish a standard curve. The FRAP antioxidant activity was expressed as $\mathrm{mM}$ of $\mathrm{Fe}^{2+}$ equivalents per $\mathrm{g}$ of samples $(\mathrm{mM}$ $\left.\mathrm{Fe}^{2+} \mathrm{E} / \mathrm{g}\right)$.

\section{Statistical Analysis}

All assays were expressed as mean \pm standard deviation (SD) from five separate experiments $(\mathrm{n}=5)$. Statistical analysis was carried out using one-way analysis of variance (ANOVA) followed by Duncan's multiple range tests. Differences at $p<0.05$ were considered to be significant.

\section{Results and Discussion}

Total phenolic compounds and total flavonoid contents

The total phenolic contents (TPC) were estimated using gallic acid, and total flavonoid contents (TFC) were estimated using rutin as a standard. Following TPC analyses, it was found that the second formula $(26.21 \pm 1.18 \mathrm{mgGE} /$ gExt) was significantly higher than the first formula $(8.00 \pm 0.14 \mathrm{mgGE} / \mathrm{gExt})$. Moreover, TFC from the second formula $(24.32 \pm 1.12$ $\mathrm{mgQE} / \mathrm{gExt}$ ) still had significantly more content than the first formula $(3.87 \pm 0.55 \mathrm{mgGE} / \mathrm{gExt})$ (Table 2). Phenolic compounds from plants, such as flavonoid, have antioxidant potential, which are risk factors for disease (Duthie \& Crozier, 2000). Furthermore, phenolic compounds are considered secondary metabolites and these phytochemical compounds derived from phenylalanine and tyrosine occur ubiquitously in plants with variable properties, and are thought to have positive effects on human health (Saeed et al., 2012).

A partial review of the literature concerning the phenolic and flavonoids of the herbs in the second formula found that the ethanol extracts of Aegle marmelos fruits have high contents of TPC (87.34 $\pm 4.44 \mathrm{mgGE} / \mathrm{g} \mathrm{DW})$ and TFC $(15.20 \pm 0.51 \mathrm{mgCE} / \mathrm{g} \mathrm{DW})$ (Charoensiddhi \& Anprung, 2008), and Ganoderma lucidum extract had TPC (40.29 mgGE/gExt) and TFC (469.9 - $627.7 \mu \mathrm{g} / \mathrm{gExt}$ ) (Gąsecka et al., 2016b). It has been reported that the aqueous extract of Pleurotus ostreatus, which is in the first formula, showed TPC $(9.64 \pm 0.33 \mathrm{mg} / \mathrm{gExt})$ and TFC $(2.11 \pm 0.19 \mathrm{mg} / \mathrm{gExt})$ (Gasecka et al., 2016a). According to Ghasemzadeh \& Jaafar (2014), studies on Pandanus amaryllifolius leaves state that methanol extract had TPC at $1.78 \mathrm{mg} / \mathrm{g} \mathrm{DW}$ and TFC at $6.601 \mathrm{mg} / \mathrm{g}$ DW.

\section{Flavonoids and Phenolic Acids}

Analysis of some flavonoid and phenolic acid composition that were beneficial to the health of herbal tea formulas were performed using reversed-phase HPLC. Generally, the same 
Table 2: The total phenolic contents (TPC) and total flavonoid contents (TFC) of different formulas of heart tonic herbal teas prepared through aqueous infusion

\begin{tabular}{lcc}
\hline Samples & TPC $(\mathbf{m g G E} / \mathbf{g E x t})$ & TFC $(\mathbf{m g R E} / \mathbf{g E x t})$ \\
\hline $1^{\text {st }}$ Formula & $8.00 \pm 0.14^{\mathrm{a}}$ & $3.87 \pm 0.55^{\mathrm{a}}$ \\
$2^{\text {nd }}$ Formula & $26.21 \pm 1.18^{\mathrm{b}}$ & $24.32 \pm 1.12^{\mathrm{b}}$ \\
\hline
\end{tabular}

TPC was measured with gallic acid equivalents (mgGE/gExt). TFC was measured with rutin equivalent (mgRE/gExt). Different superscript letters $(a, b)$ in column represented significant differences $(p<0.05)$.

flavonoid and phenolic acid compounds were present in all plant species, but there were differences in relative levels (Jorjong et al., 2015). In this study, a comparison was made between some of the flavonoids contents of different formulas of heart tonic herbal teas prepared through aqueous infusion consisting of catechin, myricetin, quercetin and kaempferol. The results showed that the first formula had significantly less flavonoid constituents than the second formula. The contents of catechin and myricetin in the first formula were $3946.26 \pm$ 98.89 and $23.06 \pm 0.03 \mu \mathrm{g} / \mathrm{g}$, respectively. The contents of catechin, myricetin and quercetin in the second formula were $36985.68 \pm 98.80$, $29.10 \pm 0.01$ and $53.24 \pm 0.01 \mu \mathrm{g} / \mathrm{g}$, respectively. However, kaempferol could not be detected in both formulas. In addition, quercetin is not found in the first formula (Table 3). Reviews of some herbs in the second formula, such as ethanol extracts from Ganoderma lucidum, detected flavonoids constituents consisting of rutin, quercetin and kaempferol (Gąsecka et al., 2016b). The extracts of Caesalpinia sappan heartwood contain many flavonoids, such as ombuin, rhamnetin, sappan chalcone and sappanol (Badami et al., 2004). The ethanol extracts of flowers of Carthamus tinctorius have kaempferol, 6-hydroxyl kaempferol and quercetin (Kazuma et al., 2000). Reviews of some herbs in the first formula reported that the extract of Pleurotus ostreatus contains flavonoids, including myricetin and naringin (Kim et al., 2008). Kaemferol, quercetin and myricetin were isolated from the petals in the flowers of Clitoria ternatea (Al-Snafi, 2016).

We also compared the phenolic acid content of different formulas from the heart tonic herbal teas prepared through aqueous infusion consisting of gallic acid, syringic acid and cumaric acid. The results showed that the first formula had significantly less phenolic acid constituents than the second formula. The first formula consisted of gallic acid, syringic acid and cumaric acid at $1667.99 \pm 91.20,52.15 \pm$ 0.01 and $66.97 \pm 0.01 \mu \mathrm{g} / \mathrm{g}$, respectively. The second formula consisted of gallic acid, syringic acid and cumaric acid at $3793.55 \pm 89.71,65.80$ \pm 0.01 and $84.51 \pm 0.01 \mu \mathrm{g} / \mathrm{g}$, respectively (Table 4). Past studies have reported that the extracts of Ganoderma lucidum in the second formula had phenolic acids constituents, consisting of chlorogenic acid, syringic acid, ferulic acid, $p$-coumaric acid, caffeic acid, 4-hydroxybenzoic acid and gallic acid, protocatechuic acid, vanillic acid, sinapic acid and t-cinnamic acid (Gąsecka et al., 2016b), while the extracts of Pleurotus ostreatus in the first formula had shown phenolic acid constituents, which consisted of chlorogenic acid, syringic acid, ferulic acid, $p$-coumaric acid, caffeic acid, $p$-hydroxybenzoic acid and gallic acid (Woldegiorgis et al., 2014).

\section{Antioxidant activity}

The radical scavenging activities of different formulas of the heart tonic herbal teas by prepared through aqueous infusion were measured using two different assays, namely DPPH and FRAP. as shown in Table 5. The results found that the antioxidant activity the second formula (16.88 $\pm 0.25 \mathrm{mgTE} / \mathrm{g}$ and $62.97 \pm 2.45 \mathrm{mM} \mathrm{Fe}^{2+} \mathrm{E} / \mathrm{g}$, respectively) detected through DPPH and FRAP was significantly higher than the first formula $(5.41 \pm 0.03 \mathrm{mgTE} / \mathrm{g}$ and $13.57 \pm 1.10 \mathrm{mM}$ $\mathrm{Fe}^{2+} \mathrm{E} / \mathrm{g}$, respectively). This is consistent with investigations of phytochemical substances, such as flavonoid and phenolic, which was found to be higher in the second formula than 
Table 3: The flavonoid contents $(\mu \mathrm{g} / \mathrm{g} \mathrm{DW})$ of different formulas of heart tonic herbal teas prepared through aqueous infusion

\begin{tabular}{lcccc}
\hline Samples & $\begin{array}{c}\text { Catechin } \\
(\mu \mathbf{g} / \mathbf{g} \text { DW })\end{array}$ & $\begin{array}{c}\text { Myricetin } \\
(\mu \mathbf{g} / \mathbf{g} \text { DW })\end{array}$ & $\begin{array}{c}\text { Quercetin }(\mu \mathbf{g} / \mathbf{g} \\
\mathbf{D W})\end{array}$ & $\begin{array}{c}\text { Kaempferol } \\
(\mu \mathbf{g} / \mathbf{g} \mathbf{D W})\end{array}$ \\
\hline $1^{\text {st }}$ Formula & $3946.26 \pm 98.89^{\mathrm{a}}$ & $23.06 \pm 0.03^{\mathrm{a}}$ & $\mathrm{ND}$ & $\mathrm{ND}$ \\
\hline $2^{\text {nd }}$ Formula & $36985.68 \pm 98.80^{\mathrm{b}}$ & $29.10 \pm 0.01^{\mathrm{b}}$ & $53.24 \pm 0.01$ & $\mathrm{ND}$ \\
\hline
\end{tabular}

Total catechin, myricetin, quercetin and kaempferol, $\mathrm{ND}=$ not determined.

Different superscript letters $(a, b)$ in column represented significant differences $(p<0.05)$.

Table 4: The phenolic acid content ( $\mu \mathrm{g} / \mathrm{g} \mathrm{DW})$ of different formulas of heart tonic herbal teas prepared through aqueous infusion

\begin{tabular}{lccc}
\hline Samples & $\begin{array}{c}\text { Gallic acid } \\
(\mu \mathbf{g} / \mathbf{g} \text { DW })\end{array}$ & $\begin{array}{c}\text { Syringic acid } \\
(\mu \mathbf{g} / \mathbf{g} \mathbf{D W})\end{array}$ & $\begin{array}{c}\text { Cumaric acid } \\
(\mu \mathbf{g} / \mathbf{g} \mathbf{D W})\end{array}$ \\
\hline $1^{\text {st }}$ Formula & $1667.99 \pm 91.20^{\mathrm{a}}$ & $52.15 \pm 0.01^{\mathrm{a}}$ & $66.97 \pm 0.01^{\mathrm{a}}$ \\
$2^{\text {nd }}$ Formula & $3793.55 \pm 89.71^{\mathrm{b}}$ & $65.80 \pm 0.01^{\mathrm{b}}$ & $84.51 \pm 0.01^{\mathrm{b}}$ \\
\hline
\end{tabular}

Total gallic acid, syringic acid and cumaric acid, ND = not determined.

Different superscript letters $(a, b)$ in column represented significant differences $(p<0.05)$.

the $1^{\text {st }}$ formula. The phenolic compounds from plants, such as flavonoid and phenolic acids, have antioxidant potential, which is a risk factor for disease (Duthie \& Crozier, 2000).

Previous studies have found that all herbs have powerful antioxidants. This result related well to the study by Yim et al. (2010), in which the aqueous extract of Pleurotus ostreatus showed an increase in antioxidant activity with the increase of concentration of extract of both DPPH (63.20\%), and $\mathrm{ABTS}^{+}$ $(87.29 \%), \quad \beta$-carotene-linoleate bleaching $(83.51 \%)$ and FRAP methods (1.45 mM FE/100 g). The propylene glycol extract of Pandanus amaryllifolius leaves showed high antioxidant activity, with an $\mathrm{IC}_{50}$ value of DPPH of $0.810 \mathrm{mg} /$ $\mathrm{mL}$ and the inhibition of peroxidation of linoleic acid of up to $90.1 \%$ (Jimtaisong \& Krisdaphong, 2013). The aqueous flowers extract of Clitoria ternatea had antioxidant activity with an $\mathrm{IC}_{50}$ value by DPPH $(1.00 \mathrm{mg} / \mathrm{mL})$, which is higher than the ethanol extract $(4.00 \mathrm{mg} / \mathrm{mL})$ (Kamkaen \& Wilkinson, 2009). According to Kozarski et al. (2011), polysaccharide extracts of Ganoderma lucidum had antioxidant activity with an $\mathrm{EC}_{50}$ value by DPPH of $7.07 \mathrm{mg} /$ $\mathrm{mL}$. Brazilin isolated from the heartwood of Caesalpinia sappan had antioxidant activity with an $\mathrm{IC}_{50}$ value by $\mathrm{ABTS}^{+}$of $28.796 \mu \mathrm{g} / \mathrm{mL}$ (Wetwitayaklung et al., 2005).

Table 5: The DPPH and FRAP radical scavenging activities of different formulas of heart tonic herbal teas prepared through aqueous infusion

\begin{tabular}{lcc}
\hline Samples & DPPH $(\mathbf{m g T E} / \mathbf{g})$ & ${\text { FRAP }\left(\mathbf{m M ~ F e}^{2+} \mathbf{E} / \mathbf{g}\right)}^{1^{\text {st }} \text { Formula }}$ \\
$2^{\text {nd }}$ Formula & $5.41 \pm 0.03^{\mathrm{a}}$ & $13.57 \pm 1.10^{\mathrm{a}}$ \\
\hline
\end{tabular}

DPPH radical scavenging activity was used with Trolox as positive control for comparison. FRAP radical scavenging activity was reducing ferrous ion $(\mathrm{Fe} 2+$ ) radical from the heart tonic herbal teas.

Different superscript letters $(a, b)$ in column represented significant differences $(p<0.05)$. 


\section{Conclusions}

Each formula of the heart tonic herbal teas was shown to have antioxidant activity based on TPC, TFC, DPPH, and FRAP. Flavonoid compounds, identified by HPLC, consisted of catechin, myricetin and quercetin while phenolics were gallic acid, syringic acid and cumaric acid. We found that the second formula contained significantly higher TPC, TFC, flavonoid compounds and phenolic compounds than the first formula. Kaempferol could not be detected in both formulas. In addition, quercetin was not found in the first formula. It can be concluded that the first heart tonic herbal tea formula does have inhibitory-free radical effects and has the potential to assist in cardiovascular health via herbal tea consumption. However, further investigations are needed to identify and characterize the major active substance in vivo through clinical research, as well as determining related biological activities and the effectiveness of other extraction methods.

\section{Acknowledgements}

This research was financially supported by the Industrial Research and Technology Capacity Development (IRTC) under the Northeastern Science Park Project by Science Park, Mahasarakham University, Maha Sarakham, Thailand.

\section{References}

Akhtar, M. S., Bashir, S., \& Malik, M. N. H. (2013). Cardiotonic activity of methanolic extract of Saussurea lappa Linn roots. Pakistan Journal of Pharmaceutical Sciences, 26(6), 1197-1201.

Alam, N., Yoon, K. N., Lee, T. S., \& Lee, U. Y. (2011). Hypolipidemic activities of dietary Pleurotus ostreatus in hypercholesterolemic rats. Mycobiology, 39(1), 45-51.

Al-Snafi, A. E. (2016). Pharmacological importance of Clitoria ternatea - A review. IOSR Journal of Pharmacy, 6(3), 68-83.

Badami, S., Moorkoth, S., \& Suresh, B. (2004).
Caesalpinia sappan - A medicinal and dye yielding plant. Indian Journal of Natural Products and Resources, 3(2), 75-82.

Benzie, I. F. F., \& Strain, J. J. (1996). The Ferric Reducing Ability of Plasma (FRAP) as a Measure of "Atioxidant Power": The FRAP Assay. Analytical Biochemistry, 239(1), 7076.

Bobek, P., Ozdin, L., \& Kajaba, I. (1997). Dosedependent hypocholesterolaemic effect of oyster mushroom (Pleurotus ostreatus) in rats. Physiological Research, 46, 327- 329.

Butkhup, L., \& Samappito, S. (2008). Analysis of anthocyanin, flavonoids and phenolic acids in tropical bignay berries. International Journal of Fruit Science, 8, 15-34.

Chan, E. W. C., \& Lim, Y. Y. (2006). Antioxidant activity of Thunbergia laurifolia tea. Journal of Tropical Forest Science, 18(2), 130-136.

Chan, E. W. C., Eng, S. Y., Tan, Y. P., Wong, Z. C., Lye, P. Y., \& Tan, L. N. (2012). Antioxidant and sensory properties of Thai Herbal Teas with emphasis on Thunbergia laurifolia Lindl. Chiang Mai Journal of Science, 39(4), 599-609.

Charoensiddhi, S., \& Anprung, P. (2008). Bioactive compounds and volatile compounds of Thai bael fruit (Aegle marmelos (L.) Correa) as a valuable source for functional food ingredients. International Food Research Journal, 15(3), 287-295.

Chiabchalard, A., \& Nooron, N. (2015). Antihyperglycemic effects of Pandanus amaryllifolius Roxb. leaf extract. Pharmacognosy Magazine, 11(41), 117122.

Choudhury, M. B. K., Rahman, T., Kakon, A. J., Hoque, N., Akhtaruzzaman, M., \& Begum, M. M., (2013). Effects of Pleurotus ostreatus on blood pressure and glycemic status of hypertensive diabetic male volunteerss. Bangladesh journal of medical biochemistr, 6(1), 5-10. 
Daisy, P., Santosh, K., \& Rajathi, M. (2009). Antihyperglycemic and antihyperlipidemic effects of Clitoria ternatea Linn. in alloxaninduced diabetic rats. African journal of microbiology research, 3(5), 287-291.

Duthie, G., \& Crozier, A. (2000). Plant-derived phenolic antioxidants. Current Opinion in Lipidology, 11(1), 43-47.

Gasecka, M., Mleczek, M., Siwulski, M., \& Niedzielski, P. (2016a). Phenolic composition and antioxidant properties of Pleurotus ostreatus and Pleurotus eryngii enriched with selenium and zinc. Eur Food Res Technol, 242, 723-732.

Gąsecka, M., Mleczek, M., Siwulski, M., Niedzielski, P., \& Kozak, L. (2016b). Phenolic and flavonoid content in Hericium erinaceus, Ganoderma lucidum, and Agrocybe aegerita under selenium addition. Acta Alimentaria, 45(2), 300-308.

Ghasemzadeh, A., \& Jaafar, H. Z. E. (2014). Optimization of Reflux Conditions for Total Flavonoid and Total Phenolic Extraction and Enhanced Antioxidant Capacity in Pandan (Pandanus amaryllifolius Roxb.) Using Response Surface Methodology. The Scientific World Journal, 2014, http:// dx.doi.org/10.1155/2014/523120.

Higashi, Y., Jitsuiki, D., Chayama, K., \& Yoshizumi, M. (2006). Edaravone (3-Methyl-1-phenyl-2-pyrazolin-5-one), a novel free radical scavenger, for treatment of cardiovascular diseases. Recent Patents on Cardiovascular Drug Discovery, 1, 8593.

Iwalokun, B. A., Usen, U. A., Otunba, A. A., \& Olukoya, D.K. (2007). Comparative phytochemical evaluation, antimicrobial and antioxidant properties of Pleurotus ostreatus. African Journal of Biotechnology, 6(15), 1732-1739.

Jimtaisong, A., \& Krisdaphong, P. (2013). Antioxidant activity of Pandanus amaryllifolius leaf and root extract and its application in topical emulsion. Tropical
Journal of Pharmaceutical Research, 12(3), 425-431.

Jorjong, S., Butkhup, L., \& Samappito, S. (2015). Phytochemicals and antioxidant capacities of Mao-Luang (Antidesma bunius L.) cultivars from Northeastern Thailand. Food Chemistry, 181, 248-255.

Kabir, K., Kimura, S., \& Tamura, T. (1998). Dietary effect of Ganoderma lucidum mushroom on blood pressure and lipid levels in spontaneously hypertensive rats (SHR). Journal of nutritional science and vitaminology, 34(4), 433-438.

Kamalakkannan, N., \& Prince, P. S. M. (2003). Hypoglycaemic effect of water extracts of Aegle marmelos fruits in streptozotocin diabetic rats. Journal of Ethnopharmacology, 87(2-3), 207-210.

Kamalakkannan, N., \& Prince, P. S. M. (2004). Antihyperlipidaemic effect of Aegle marmelos fruit extract in streptozotocininduced diabetes in rats. Journal of the Science of Food and Agriculture, 85(4), 569-573.

Kamkaen, N., \& Wilkinson, J.M. (2009). The antioxidant activity of Clitoria ternatea flower petal extracts and eye gel. Phytotherapy Research, 23(11), 1624-1625.

Kazuma, K., Takahashi, T., Sato, K., Takeuchi, K., Matsumoto, T., \& Okuno, T. (2000). Quinochalcones and flavonoids from fresh florets in different cultivars of Carthamus tinctorius L. Bioscience, Biotechnology, and Biochemistry, 64(8), 1588-1599.

Kozarski, M., Klaus, A., Niksic, M., Jakovljevic, D., Helsper, J. P. F. G., \& Griensven, L. J. L. D. V. (2011). Antioxidative and immunomodulating activities of polysaccharide extracts of the medicinal mushrooms Agaricus bisporus, Agaricus brasiliensis, Ganoderma lucidum and Phellinus linteus. Food Chemistry, 129(4), 1667-1675.

Pawar, C. R., Landge, A. D., \& Surana, S. J. (2008). Phytochemical and pharmacological 
aspects of Caesalpinia sappan. Journal of Pharmacy Research, 1(2), 131-138.

Prasattong,P.,Pakdeechote,P., Kukongviriyapan, U., Prachaney, P., \& Tangsujarit, P. (2014). Carthamus tinctorius Linn. reduce blood pressure and oxidative stress markers in nitric oxide-deficient hypertensive rats. Srinagarind Medical Journal, 29(4), 146149.

Rahimi, P., Asgary, S., \& Kabiri, N. (2014). Hepatoprotective and hypolipidemic effects of Carthamus tinctorius oil in alloxaninduced type 1 diabetic rats. Journal of HerbMed Pharmacology, 3(2), 107-111.

Ravikumar, C. (2014). Review on Herbal Teas. Journal of Pharmaceutical Sciences and Research, 6(5), 236-238.

Saeed, N., Khan, M. R., \& Shabbir, M. (2012). Antioxidant activity, total phenolic and total flavonoid contents of whole plant extracts Torilis leptophylla L. BMC Complementary and Alternative Medicine, 12(221), 1-12.

Semsang, N., Kawaree, R., Cutler, R. W., Chundet, R., Yu, L. D., \& Anuntalabhochai, S. (2012). Improved antioxidant activity of BKOS Thai jasmine rice. Natural Product Research: Formerly Natural Product Letters, 26, 12, 1145-1151.

Sharma, V., \& Agarwal, A. (2015). Physicochemical and Antioxidant Assays of Methanol and Hydromethanol Extract of Ariel Parts of Indigofera tinctoria Linn. Indian Journal of Pharmaceutical Sciences, 77(6), 729-734.

Singleton, V. L., Orthofer, R., \& LamuelaRaventos, R.M. (1999). Analysis of total phenols and other oxidation substrates and antioxidants by means of folin- ciocalteu reagent. Methods in Enzymology, 299, 152178.

Sripum, C., Kukreja, R. K., Charoenkiatkul, S., Kriengsinyos, W. and Suttisansanee, U. (2017). The effect of extraction conditions on antioxidant activities and total phenolic contents of different processed Thai Jasmine rice. International Food Research Journal, 24(4), 1644-1650.

Trivedi, P. C., \& Nehra, S. (2004). In: Trivedi PC editor. Herbal drugs and biotechnology, Plant which cures heart disease. Pointer Publishers, Jaipur, India, p. 3.

Ursini, F., Maiorino, M., Morazzoni, P., Roveri, A., \& Pifferi, G. (1994). A novel antioxidant flavonoid (IdB 1031) affecting molecular mechanisms of cellular activation. Free Radical Biology and Medicine, 16(5), 547-553.

Wetwitayaklung, P., Phaechamud, T., \& Keokitichai, S. (2005). The antioxidant activity of Caesalpinia sappan L. heartwood in various ages. Naresuan University Journal, 13(2), 43-52.

WHO. (2017). Cardiovascular diseases (CVDs). Retrieved May 12, 2020, from https://www. who.int/en/news-room/fact-sheets/detail/ cardiovascular-diseases-(cvds).

Woldegiorgis, A. Z., Abate, D., Haki, G. D., \& Ziegler, G. R. (2014). Antioxidant property of edible mushrooms collected from Ethiopia. Food Chemistry, 157, 30-36.

Yan, Y., Chen, Y., Lin, Y., Guo, J., Niu, Z., \& Li, L., (2015). Brazilin isolated from the heartwood of Caesalpinia sappan L induces endothelium-dependent and -independent relaxation of rat aortic rings. Acta Pharmacologica Sinica, 36, 1318-1326.

Yim, H. S., Chye, F. Y., Tan, C. T., Ng, Y. C., \& Ho, C. W. (2010). Antioxidant Activities and Total Phenolic Content of Aqueous Extract of Pleurotus ostreatus (Cultivated Oyster Mushroom). Malaysian Journal of Nutrition, 16(2), 281-291.

Zhang, P. Y., Xu, X., \& Li, X. C. (2014). Cardiovascular diseases: oxidative damage and antioxidant protection. European Review for Medical and Pharmacological Sciences, 18, 3091-3096.

Zhang, X. (2000). Guidelines for levels and kinds of evidence to support claims for therapeutic goods. In: Zhang X (editor). 
General guidelines for methodologies on research and evaluation of traditional medicine. World Health Organization, Geneva, Switzerland, p.41.

Zhang, Y., Hu, T., Zhou, H., Zhang, Y., Jin, G., \& Yang, Y. (2016). Antidiabetic effect of polysaccharides from Pleurotus ostreatus in streptozotocin-induced diabetic rats.
International Journal of Biological Macromolecules, 83, 126-132.

Zhao, Q., Matsumoto, K., Okada, H., Ichiki, H., \& Sakakibara, I. (2008). Anti-hypertensive and anti-stroke effects of Chrysanthemum extracts in stroke-prone spontaneously hypertensive rats. Journal of Traditional Medicines, 25(5-6), 143-151. 